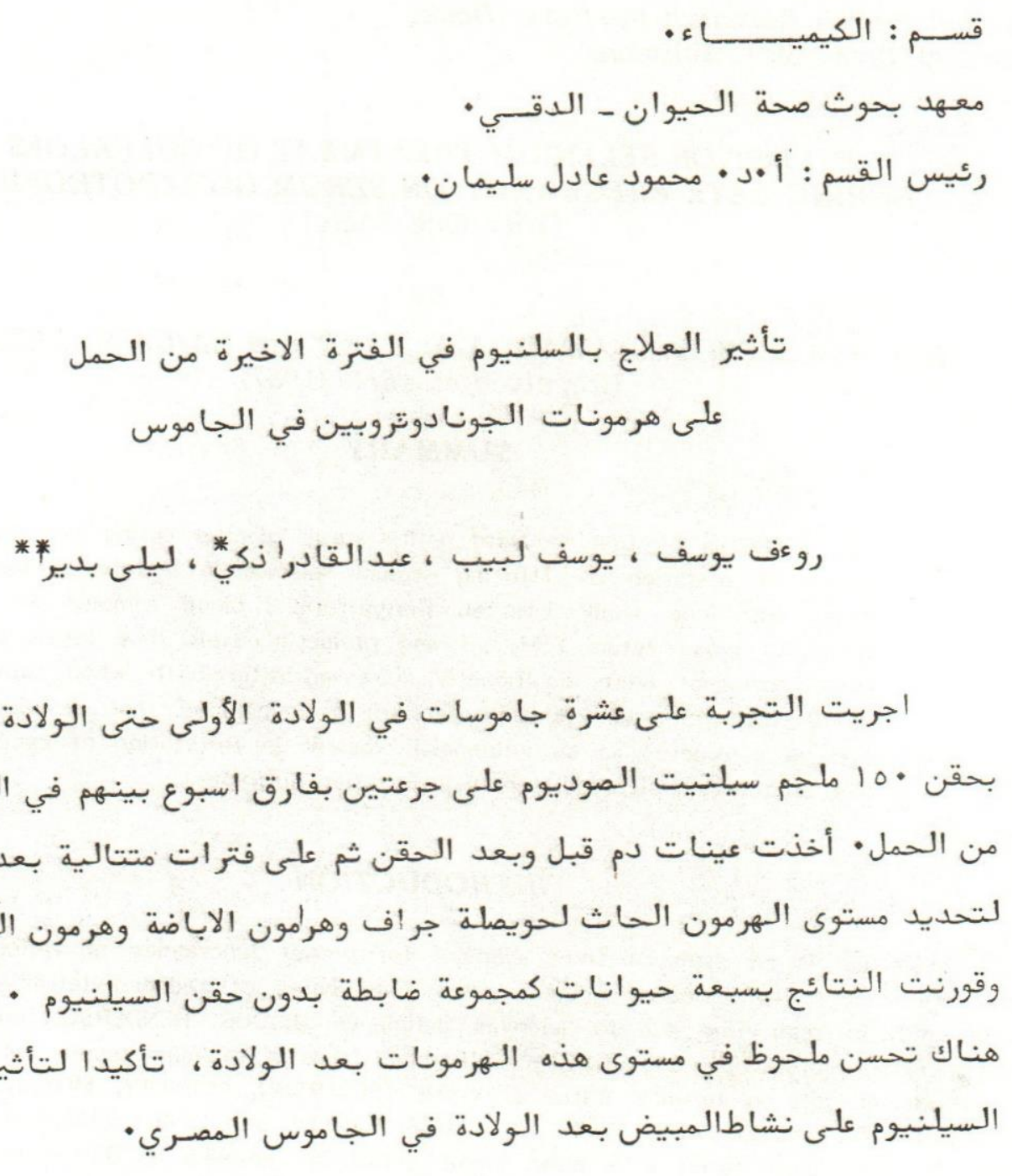

* : كلية الطب البيطري - جامعة القاهرة • ***: معهد بحوث الانتاج الحيواني بالدقي. 
Dept. of Biochemistry,

Animal Health Research Institute, Dokki,

Head of Dept. M.A. Soliman.

\title{
EFFECT OF SELENIUM TREATMENT OF BUFFALOES DURING LATE PREGNANCY ON SERUM GONADOTROPHINS (With One Table)
}

\author{
By \\ R.H. YOUSSEF; Y.L. AWAD; A.A. ZAKI* and LAILA H. BEDAIR** \\ (Received at 15/11/1987)
}

SUMMARY

\begin{abstract}
The buffaloes of first to third parity were injected during the last month of gestation by $150 \mathrm{mg}$ sodium selenite in a rate of two doses with one week interval. Periparturient blood samples were taken to assay serum FSH, LH and prolactin levels. The levels of these hormones were significantly increased after birth when compared with the non-treated cases. It is concluded that selenium can be considered as an influencial element in restoration of cyclic ovarian function after parturition in Egyptian buffaloes.
\end{abstract}

\section{INTRODUCTION}

Selenium is an essential trace element for proper functioning of various reproductive characteristics in domesticated animals. Most field cases of reduced fertility of nutritional origin may in reality be due to selenium deficiency (BLOOD, HENDERSON and RADOSTITIS, 1979; LARSON, MABRUCK and LOWRY, 1980). Field trials of selenium supplementation, indicated its important role in fertility status of cattle (SEGERSON, MURRAY, MOXON, REDMAN and CONRAD, 1977 and BLOWEY, 1982). MC CLURE, EAMENS and HEALY (1986) found that dairy cows in three dairy farms with mean blood glutathione peroxidase (GSH - Px) activities of $\angle 70$ units/g haemoglobin, showed a significant improvement in first service conception rates following treatment with oral selenium pellets. In Egyptian buffaloes, AWAD, YOUSSEF and MIKHAIL (1985) recorded favourable influences of the prepartum selenium treatment on the reproductive pattern by reducing the postpartum service period, open days and number of services per conception.

There are no previous evidences concerning the effect of selenium supplementation on endocrine parameters. The present study was planned to determine its effect on pituitary gonadotrophins in Egyptian buffaloes.

\section{MATERIAL and METHDODS}

Buffaloes in a Breeding Center at Mehallit Mousa, Kafr El-Sheikh Province in which parturient animals has a previous history of nutritional muscular dystrophy of their calves, were chosen for our experiment. Ten animals of first to third calving sequence were injected during the last month of gestation by selenium as acid sodium selenite. The drug was given intramuscularly in a dose of $150 \mathrm{mg}$ at a rate of two doses with one week inbetween. Blood

*: Faculty of Veterinary Medicine, Cairo University.

**: Animal Production Research Institute, Dokki, Giza.

Assiut Vet.Med.J.Vol. 20, No. 39, 1988. 
Rd. YOUSSEF et al.

samples were taken before and 7 days after treatment, then at birth and 10, 20, 30, 40 and 50 days after calving $(0,+10,+30,+40,+50)$. On the other hand, seven buffaloes of the same age were left without treatment as a control and blood samples were obtained in the same manner.

Buffalo follicle stimulating hormone (FSH) and luteinizing hormone (LH) were prepared from buffalo pituitaries according to ZAKI (1986). These hormones were standardized by using the methods of STEELMAN and POHLY (1955) for FSH and SOLIMAN (1960) for LH. While, standard boving prolactin hormone (USDA-b P.RL-B-1, AFP-5300) was received from National Institute of Diabetes, Digestive and Kidney Diseases (NIDDK- USA). The specific antisera of these hormones were prepared by the method of TADEUSZ (1971). In order to confirm the specificity of the prepared rabbit antisera, cross reaction test was done among these antisera and their specific sensitized sheep red cells. The result showed that reaction occurred only between each antiserum and its specific hormone - sensitized sheep red cells. Sera of blood samples were assayed for FSH, LH and PRL using immunoassay methods, (Agglutination inhibition) according to WIDE (1962) and SCHUURS (1969) as described by EL-GHANDOUR (1985). The computation of hormone concentration and statistical analysis of data were carried out according to DIXON and MASSAY (1957).

\section{RESULTS}

Hormonal profile (FSH, LH and PRL) in buffaloe sera, during the last month of pregnancy up to 50 days after birth in control and treated animals are presented in Table 1 and Figure 1. Significant increase of these hormones were noticed in different periods after birth in the treated cases. FSH $L$ LH ratio differed significantly after selenium treatment. Its pattern was clarified in Figure 1.

\section{DISCUSSION}

The results showed that in control buffaloes, the FSH levels during the last month of pregnancy until 20 days after birth were significantly higher ( $P \angle 0.01$ ) than the levels at the subsequent period of the experiment. In accordance to our results, AHMED (1980) reproted that FSH level in buffalo serum, 19 days after parturition, was higher than on days 30, 54, 66 and 75. In the present study, the dams randomly chosen for treatment had a significantly lower values of FSH level (PL 0.05) than control buffaloes. After treatment, the level increased to a higher value at day 10 postpartum with significant difference $(P \angle 0.001)$ and remained slightly higher than in control animals after that.

The mean serum $\mathrm{LH}$ level in control animals started to increase at 10 days postpartum and reached its peak at day 20 then dropped to a lower level on day 50 after birth. The same result was reported in cattle by ZVEREVA et al. (1981) and MADEJ et al. (1984). However, in Egyptian buffaloes, ABDO (1962) and AHMED (1980) and in cattle, ERB et al. (1971) and ARIJE et al. (1974) found that LH level did not change during 75 and 60 days postpartum in buffaloes and cows respectively. Favourable results were obtained after selenium treatment in concern with LH level. Its level increased significantly when comparing with the control cases at days 10,30 and 50 .

FSH/LH ratio of the same serum samples (JANAKIRAMAN \& SHETH,1978 \& JANAKIRAMAN et al., 1980) has two peaks in treated cases, the first at one week after selenium injection and the second on day 40 postpartum. While, in control animals the ratio decreased significantly and sharply increased only at 50 day after birth.

Assiut Vet.Med.J.Vol. 20, No. 39, 1988. 


\section{SELENIUM TREATMENT, GONADOTROPHINS}

The results showed that the levels of serum prolactin in control buffaloes during the period of experiment fluctuated between 0.15 to $0.21 \mathrm{i} . u . / \mathrm{ml}$. The same result was obtained by AHMED (1980) who reported that the serum level of prolactin in buffaloes did not differ significantly during the first 75 days postpartum. In the case of cows, ARIJE et al. (1974) recorded that the level of this hormone fluctuated from $50 \mathrm{ng} / \mathrm{ml}$ to above $300 \overline{\mathrm{ng}} / \mathrm{ml}$ during the first 20 days postpartum and then ranged between 100 to $200 \mathrm{ng} / \mathrm{ml}$. ZVEREVA et al. (1981) detected a sharp increase of prolactin concentration in blood serum at 16-18 days after calving in Russian Black Pied cows. In selenium treated cases, the prolactin level increased significantly $(P \perp 0.05)$ one week after injection, then dropped at birth, to increase after 10 days and dropped at day 40 (Table 1 and Figure 1). Soliman (1964) concluded the necessity for a proper supply of prlactin to maintain proper functional activity of the ovaries in buffaloes. MADEj et al. (1984) found a partial correlation between the log values of prolactin and $\mathrm{LH}$ at the intervals of $7-9,21-23$ and $49-51$ days postpartum $(0.2, P \angle 0.05)$, similar to the results obtained in our experiment.

From the aforementioned results, the authors concluded that prepartum selenium treatment can improve the reproductive efficiency after birth in buffaloes, by its direct effect on the pituitary gland activity. This supports the previous field results recorded in buffaloes by AWAD et al. (1985) and in cows by HARRISON et al. (1981); SANDERS (1984) and Mc CLURE et al. (1986).

\section{ACKNOWLEDGEMENT}

Deepest thanks are due to Prof. Dr. F.A. SOLIMAN, Professor of Physiology, Fac. Vet. Med., Cairo University for his kind help and also to Prof. Dr. SALVATOR RAITI, M.D., Director of National Hormone and Pituitary Program, NIDDK, USA, for his generous supply of bovine prolactin.

\section{REFERENCES}

Abdo, M.S. (1962): Hormonal variations in the blood of buffaloes during pregnancy. M.D.Vet. Thesis, Cairo University.

Ahmed, H.A. (1980): Postpartum hormonal changes in the blood of buffaloes. Ph.D. Thesis, Cairo University.

Arije, G.R., Wiltbank, J.M. and Hopwood, M.L. (1974): Hormone levels in pre and postparturient beef cows. J. Anim. Sci, 39 (2), 330-347.

Awad, Y.L.; Youssef, R.H. and Mikhail, M.F. (1985): Influence of prepartum selenium treatment on the reproductive pattern of Egyptian buffaloes and on the born calves. Egypt. J. Vet. Sci., 22, 55-64.

Blood, D.C., Henderson, J.A. and Radostits, O.M. (1979): "Veterinary Medicine". 5th Ed., The English Language Book Society and Bailliere Tindall, 891-903.

Blowey, R.W. (1982): Primary evaluation of water soluble selenium tablets in the treatment of selenium deficiency in dairy cattle. Vet. Rec., 110, 477-480.

Dixon, W.J. and Massay, F.J. (1957): Introduction to Statistical Analysis. (2nd Ed.), Mc-Grow Hill Book Co., TMC, New York.

El-Ghandour, S.E.M. (1985): Role of gonadotrophin binding proteins in regulating reproductive performance of cows and buffaloes. Ph.D. Thesis, Cairo University.

Erp R.E., Surve A.H., Callahan C.L., Randel R.D. and Garverick H.A. (1971): Reproductive steroids in the bovine. III: Changes postpartum. J. Anim. Sci., 33, 1060-1071.

Harrison, J.H., Hancock, D.D. and Conrad, H.R. (1981): Ensiled forages, selenium injections, cystic ovaries, retained placenta and metritis. J. Dairy Sci., 64 (Suppl. 1), 150. 


\section{R.H. YOUSSEF et al.}

Janakiraman, K. and Sheth, A.R. (1978): Serum gonadotropins and prolactin in water buffalo in relation to its reproductive performance. (Abstr.) Fourth All-India Congress of Zoology (Endocrinology Section), held from 18 to 22 October, 1978, at Magadth University, Bodh Gaya (Bihas).

Janakiraman, K., Desai, M.C., Amin, Darshana, R. Moodbidri, S.B., Wadedkar, K.B. and Sheth, A.R. (1980): Serum gonadotropin levels in buffaloes in relation to its reproductive performance. Indian J. Anim. Sci., 50, 601-606.

Larson, L.L., Mabruck, H.S. and Lowry, S.R. (1980): Relationship between early postpartum blood composition and reproductive performance in dairy cattle. J. Dairy Sci., 63, 283-289.

Madej, A., Oyedipe, E.O., Edqvist, L.E. and Kindahl, H. (1984): Prolactin and LH in postpartum suckling cows. In 10th Internaltional Congress on Animal Reproduction of Illinois at Urbana-Champaign, Illinois, USA. Volume Ill. Brief communications. Urbana, USA, University of llinois (1984) Paper No. 403, pp.3.

McClure, T.J., Eamens, G.J. and Healy, P.J. (1986): Improved fertility in dairy cows after treatment with selenium pellets. Aust. Vet. J., 63, 144-146.

Sanders, D.E. (1984): Use of selenium in problem cattle herds. Modern Veterinary Practica, 136-138.

Schuurs, A.H.W.M. (1969): Agglutination inhibition reactions for the determination of gonadotrophin. Karolinska Symposia in Research method in Reproductive Endocrinology. 1st symposium, Immunoassay of Gonadotrophins, Stockholm, 95-112.

Segerson, E.C., Murray, F.A., Moxon, A.L., Redman, D.R. and Conrad, H.R. (1977): Selenium/ vitamin E: role in fertilization of bovine ova. J. Dairy Sci., 60: 1001-1005.

Soliman, F.A. (1960): Assay of luteinizing hormones. Nature, 185, 321-323.

Soliman, F.A. (1984): Problems of fertility of buffaloes. Possible solutions. First National Conference on Physiological Sciences, Cairo, March, 31-April, 2.

Steelman, S.L. and Pohley, F.M. (1955): Assay of the follicle stimulating hormone based on the augmentation with human chorionic gonadotropin. Endocrinology, 55, 604-616.

Tadeusz, s. (1971): Attempts to determine immunologically the activity of pregnant mare serum gonadotrophins. Bull. Vet. Inst. Pulawy, 18, 108-111.

Wide, L. (1962): An immunological methods for the assay of human chorionic gonadotrophin. Acta Endocr. (Copenh.), 41, 70-73.

Zaki, A.A. (1986): Study of follicle stimulating hormone and luteinizing hormone receptors in ovarian tissues of buffaloes. Ph.D. Thesis, Cairo University.

Zvereva, G.V., Lebedev, A.G., Lipinskii, B.V., Dmitriev, B.V. and Stepanov, G.S. (1981): The relationship among hormones during the period of restoration of oestrous cycle in postparturient cows. Doklady Vsesoyuznoi Akademii Sel' Skokhozyaistvennykh Nauk, 2, 33-35.

Assiut Vet.Med.J.Vol. 20, No. 39, 1988. 
SELENIUM TREATMENT, GONADOTROPHINS






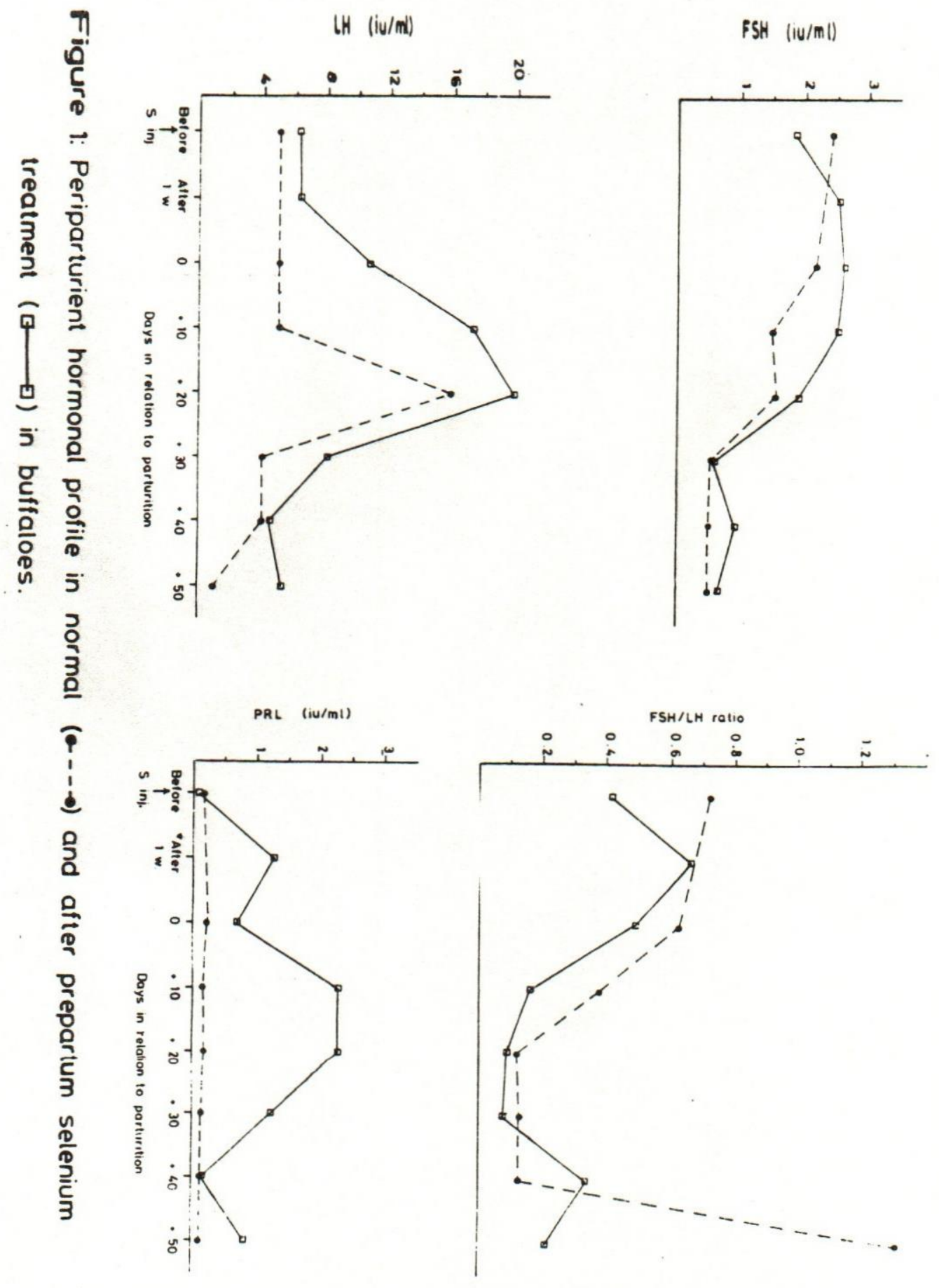


